\title{
Technopolitics, connective action and convergent activism: emerging communication practices from ecosocial struggles
}

Tecnopolitica, acción conectiva y activismo convergente: prácticas comunicacionales emergentes de las luchas ecosociales

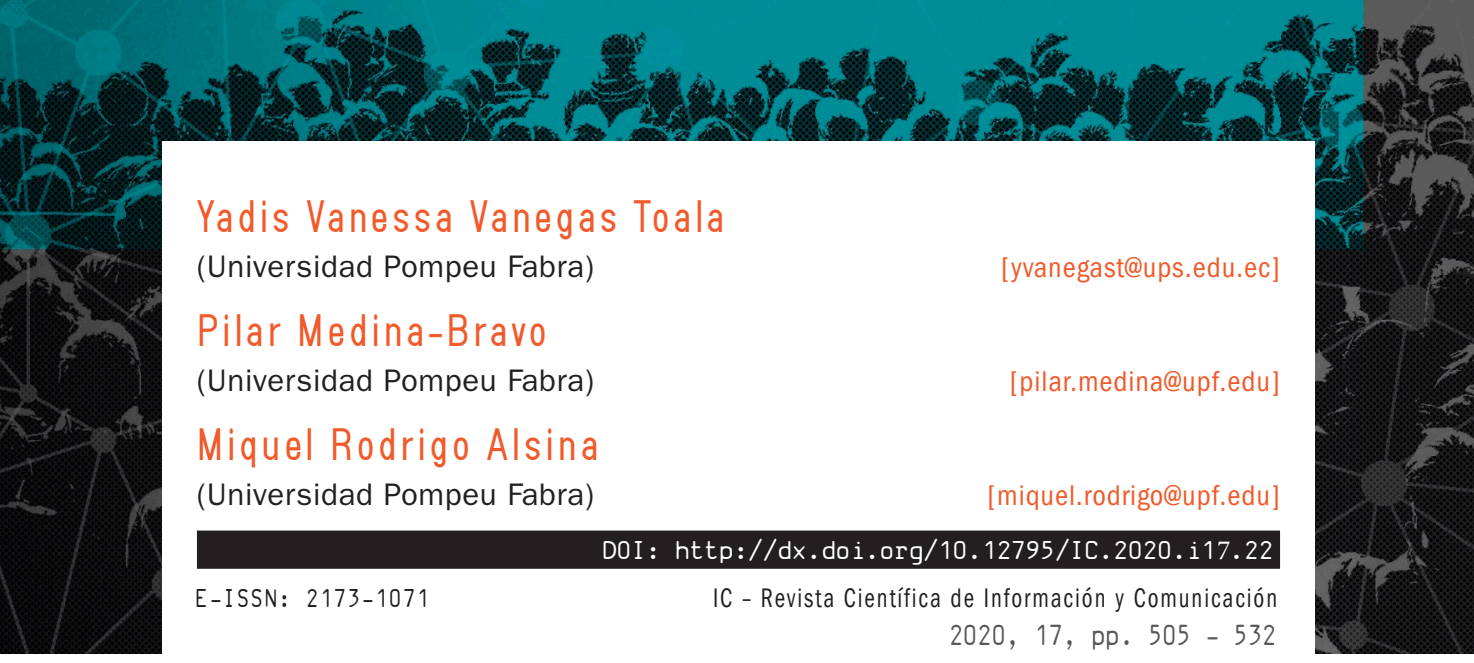

Abstract

This article draws on the notion of technopolitics to analyze the reconfiguration of collective networked action of eco-social activism, based on the study of \#SOSPuebloShuar on Twitter. Through the method of social network analysis, the main political actors and their relationships are mapped, as a strategy to characterize the connective action that preconfigures a collaborative and convergent activism, based on ethno-cultural, ecological-territorial and human rights claims.

\section{Resumen}

Este artículo parte de la noción de tecnopolítica para analizar la reconfiguración de la acción colectiva en red del activismo ecosocial, a partir del estudio de \#SOSPuebloShuar en Twitter. A travésdel método de análisis de redes sociales, se mapea los principales actores políticos y sus relaciones, como estrategia para caracterizar la acción conectiva que preconfigura un activismo colaborativo y convergente, basado en reivindicaciones étnico-culturales, ecológico-territoriales y de derechos humanos.

\section{Keywords}

Tecnopolitics, connective action, ecosocial activism, collective action, Shuar indigenous, social network analysis. 


\section{Palabras clave}

Tecnopolítica, acción conectiva, activismo ecosocial, acción colectiva, indígenas Shuar, análisis de redes sociales.

\section{Summary}

1. Introduction

2. Sociopolitical context of \#SOSPuebloShuar

3. Literature review

3.1 Social movements, activist networks, and ICTs.

3.2 Communication-connective action as a new collective action paradigm

3.3 Technopolitics as a hybrid strategy of contemporary activism

4. Method: SNA and graph visualization

4.1 Data collection

4.2 Mapping the main actors (key nodes) RQ1

4.3 Structural relations (clusters) RQ2

4.4 Connective action and convergent activism analysis RQ3

5. Results and discussion

5.1 Mapping the main actors in \#SOSPuebloShuar - RQ1

5.2 Structural relations in the main actors in \#SOSPuebloShuar-RQ2

5.3 Convergent activism analysis: the reconfiguration of the networked collective action strategy - RQ3

6. Conclusions

7. Bibliography

Sumario

1. Introducción

2. Contexto sociopolítico de \#SOSPuebloShuar

3. Revisión de literatura

3.1 Movimientos sociales, redes activistas y TIC

3.2 La acción comunicativa-conectiva como nuevo paradigma de acción colectiva

3.3 La tecnopolítica como estrategia híbrida del activismo contemporáneo

4. Método: SNA y visualización de gráficos

4.1 Mapeo de los principales actores (nodos clave)

4.2 Relaciones estructurales (clusters) RQ2

4.3 Acción conectiva y análisis de activismo convergente $R Q 3$

5. Resultados y discusión

5.1 Mapeo de los principales actores en \#SOSPuebloShuar - RQ1

5.2 Relaciones estructurales en los principales actores en \#SOSPuebloShuar - RQ2

5.3 Análisis del activismo convergente: la reconfiguración de la estrategia de acción colectiva en red - RQ3

6. Conclusiones

7. Bibliografía 


\section{Introduction}

The contemporary media ecology, fuelled by accelerated development of the information and communication technologies (ICTs), has transformed the communication practices of activists within a socio-communicative and socio-political dimension (Rovira, 2013). Technologically mediated global protest movements, such as the Arab Spring (2011), Occupy Wall Street (2011), the 15M Movement (2011), YoSoy132 (2012) and Nuit Debout (2016), have been studied from the perspective of that reconfiguration (Castells, 2012; Costanza-Chock, 2012; Pérez-Altable \& Blanco, 2016; Reguillo, 2017; Toret, 2013). Bearing in mind that networked society is characterized by a high degree of interconnectedness through digital technologies (Castells, 2009) social network analysis (SNA) is an ideal method to study social movements (Caiani, 2014) from an interdisciplinary perspective straddling sociology and communication.

SNA focuses on the relationships and interactions among the actors in a network. The organizational structure is analyzed in terms of the position and linkages of each actor, which represents opportunities or constraints for collective action (Caiani, 2014, p. 368). In a study of social movements using SNA, it is useful to identify activists whose strategy is to generate coalitions.In this context, research into the sociotechnical-communicative role of the hashtag in social protest has become increasingly important (Rambukkana, 2015).For instance, Waiwai Wayne Xu (2020) examines, from the theoretical framework of connective action and the SNA method, the configuration of counterpublics and counteridentities by studying the hashtags used by Alt-Right and Antifa on Twitter-based. He concludes that digitally mediated supports the vindications of each movement. Also, Rachel Kuo (2018) uses SNA to understand the circulation of activist discourse in her analyses of \#NotYourAsianSideKick and \#SolidarityisforWhiteWomen from the perspective of the intersection of race and gender variables.

Based on those considerations, we used SNA to analyze ecosocial struggles configured around the Twitter hashtag \#SOSPuebloShuar, as an emerging activist communication practice, in response to the socio-environmental conflicts experienced by the Shuar indigenous people in the Ecuadorian Amazon, due to large-scale mining projects. The SNA led to the processing of a total of 32,835 tweets generated between 16 December 2016 and 28 May 2017,a period that saw consolidation of the San Carlos-Panatza large-scale mining project in Shuar territory.Our general objective was to analyse the reconfiguration of the networked collective action from the topology study of 
\#SOSPuebloShuar, based on the mapping of the main actors and the type of strategic relations to optimize political opportunities. We propose the following research questions:

RQ1: Who are the main actors representing the key nodes of the network and what kind of sector they represent?

RQ2: What kind of structural relations (cooperation, disagreement, influence) exist among the key nodes in the network?

RQ3: How does these relations impact the configuration of collective action of the ecosocial activism to optimize political opportunities?

To understand the reconfiguration of collective action, the results of the SNA were analyzed contemplating the social interactions between the main actors in the network, considering the socio-historical and political context of ecosocial activism. The agency of the actors within a framework of political opportunities was therefore prioritized over an analysis anchored in technological mediation. This perspective arises from a complex understanding of contemporary media activist practices that seeks to move away from the communicative reductionism implied by technological determinism, as proposed by Treré (2019).

\section{Sociopolitical context of \#SOSPuebloShuar}

State extractive policies and the concession of $15.25 \%$ of the national territory to transnational companies have consolidated large-scale mining activities in Ecuador.Thus, 41,760 hectares of Shuar territories have been granted to a chinese transnational company for its Carlos-Panatza copper mining project. However, the fact that the indigenous people were not consulted about the concession breaches their fundamental right of free and informed prior consultation, a mandatory democratic process that is internationally (Convention 169, ILO 1989) and nationally (Constitution of the Republic of Ecuador, 2008) recognized.

The socio-political context of \#SOSPuebloShuar is characterized by territorial disputes and by a conflict of rationalities. The indigenous worldview defends the ancestrally of their territories and rejects mining activities, whilemodern state rationality argues that large-scale mining is necessary for economic development.Mining projects in this kind 
of context have frequently caused socio-environmental conflicts marked by human rights violations.The San Carlos-Panatza project is emblematic, given the escalation of violence against the Shuar people, who have experienced forced displacement, militarization, a declaration of a state of emergency, criminalization of social protest and censored freedom of expression. The issue has been investigated from the perspectives of sociology, political ecology and collective health (Báez, Bayón, Larreátegui, Moreano, \& Sacher, 2016; Colectivo de Investigación y Acción Psicosocial Ecuador, 2017; Sacher, 2017)

On August 11, 2016, the Armed Forces forcibly evicted the Shuar community of Nankints to set up the base camp for the extractive project. On 21 November 2016, the indigenous people carried out an action to recover their territory. In response, the Armed Forces laid siege by territories and air to the Shuar Tink, Warits and Tsuntsuim communities -where the displaced people were sheltering. Finally, on 14 December 2016, the government declared militarization of the area and a state of emergency, while launching legal proceedings to criminalize the protesting Shuar indigenous leaders (Foro Social Panamazónico, 2017). This set of events generated different civil society actors to develop an ecosocial activism. The \#SOSPuebloShuar involved multiple forms of collective action: in the digital space, with activist communication repertoires in social networks; in the physical space, with direct actions such as marches and sit-ins. (Confederación de Nacionalidades Indígenas del Ecuador, 2017; El Comercio, 2016, 2017).

\section{Literature review}

\subsection{Social movements, activist networks and ICTs}

The social movements of the 21st century have incorporated ICTs into their organizational structures and advocacy actions(Tilly \& Wood, 2010, p. 193). These constitutive transformations have reconfigured the socio-political dynamics of contemporary activism, challenging classical social movement theory to renew itself (Reguillo, 2018; Rovira, 2017; Toret, 2013). In the traditional definition of a social movement, actors shared a collective identity with belonging to a sector in the social structure, e.g., workers, indigenous, peasants, feminists, students, etc.This collective identity formed the basis for a common aspiration to tackle a shared problem, withactions organized in sustained interaction sequences and using a strategy of confrontationin a dynamic referred to as collective action (Tarrow, 1997, p. 19). 
However, technological mediation has impacted the ways in which current activism is configured. The most important change is that the principle of collective identity as the backbone of struggles has been displaced. ICTs facilitate connection between heterogeneous actors who may not necessarily share the same collective identity, but who do share a common political objective. Authors such as Rosana Reguillo (2017) observe how this dynamic represents a new social form of 'embodiment' of resistance (2017, p. 62). Activist networks are thus replacing the traditional affiliative identity of social movements by fostering ICT-facilitated configuration of a network of connected multitudes.

Several theoretical perspectives on technological mediation in activism have limited themselves to explaining it as a phenomenon exclusive to the digital sphere: cyber-protest (Van de Donk, Loader, Nixon, \& Rucht, 2004), cyberpolitics (Bell, 2006) and cyberactivism (Tascón \& Quintana, 2012). Beyond this biased vision of the Internet space, Castells (2012) argues that networked social movements are characterized by their articulation of multimodal connectivity. This connection includes online and offline social networks, as well as pre-existing social networks and others formed during the movement's actions. The networks are within the movement and connect with other movements in the world, in the blogosphere, in the media and in society in general (Castells, 2012, p. 212).

Connectivity is central to contemporary activism. Rather than adopt a binary perspective that views the virtual space as separate from the physical space, networked movements are integrated through multiple channels, with collective action managed both online and offline through a strategic use of the ICTs (Reguillo, 2017; Toret, 2015) In this framework, political agency is fuelled by technologically mediated cooperative and collaborative practices. Indeed, a sociotechnical and sociopolitical turn occurs in which the activist network is constituted as a 'network actor' (Latour, 2005), balanced between but not subject to technological determinism or social determinism.

Multimodal connections occur within a triadic framework of mediation opportunities: mediatic, discursive and networked (Cammaerts, 2012, p. 120). From a classical perspective, collective action has traditionally been considered as shared action in pursuit of some common goal and as requiring organizational capacity to transform mobilization into action within a framework of political opportunities (Tarrow, 1997, p. 40). According to Cammaerts (2012), ICT-mediated resistance builds on networked mediation opportunities structure in both the organizational sphere, i.e., in how actions are coordinated, and in the communication sphere, i.e., in the thies the discursive back to actions. "ICTs increasingly sustain movements, coordinate direct action and have become tools of direct action in their own right”(Cammaerts, 2012, p. 122). 


\subsection{Communication-connective action as a new collective action paradigm}

The concept of connective action (Bennett \& Segerberg, 2014) recognizes technological mediation as an organizing agent for both the network and collective action. From this perspective, since the dynamics of action is configured through self-organizing processes arising from participant interactions, its logic requires no institutional control. This contemporary vision contrasts with the resource mobilization theory (RMT) that traditionally explained social movements. According to RMT, collective action depends on the ability of a movement to establish itself as a material and symbolic resource management organization(McCarthy \& Zald, 1977). The shift towards connective action therefore implies technologically organized, less institutionalized and more individualized communication processes, communication itself becomes an organizational structure (Bennett \& Segerberg, 2014, p. 760).

Rovira (2017) emphasizes that the connected multitude is configured by the interactions of a multiplicity of actors; whose individual political subjectivity is transformed into collective and directs political action in a performative dimension. The dynamics of connected multitudes is such that political action is possible by social actors who are generally excluded from the political sphere. In this sense, connective action has been linked to the demand for participation: "Participation as a litigation that institutes politics and not that derives from it. Participation as a dispute over words"(Reguillo, 2017, p. 102). Connectivity has reconfigured the communicational and organizational practices of activism. In terms of Bennett and Segerberg (2012)to Occupy Wall Street (and beyond, in the logic of connective action, communication stands out as an organizing principle of collective action.

Communication plays an increasingly important role in networked movements. Passy (2002) argues that a network of political actors can be conceived as an interactive structure of collective significance. Thus, the possibility of generating agency implies the ability to make sense of the demands of the movement. The concepts of mass selfcommunication and interactive meaning production point directly to the autonomous potential of networked movements to generate their own communicative content and circuits (Castells, 2012, p. 88).Alice Mattoni (2013)defines activist communication repertoires as activist media practices in the latent and visible phase of mobilization. These are classified into two categories: media knowledge practices as strategic actions in terms of the media ecosystem in which the movement operates; and, relational media practices appealing to the interrelationship they generate with other media or organizations (Mattoni, 2013, p. 47). 
In this context, Rovira (2017)emphasizes that the most significant change in contemporary protest repertoires has to do with the leading role assumed by communication, ranging from the impact of the ICTs on tactical occupation and resistance innovations to the semantic function of endowing meaning to demands. For this reason, Rovira (2017) argues that activist networks are the new paradigm of collective action:"the contentious collective action has become communicative action"(2017, p. 94).Complementing this position, Francisco Sierra (2017)proposes that intelligent multitudes have appropriated technologies with other models of mediation, which reformulates the processes of participatory communication, historically present in social movements, especially, in Latin America. In line with these theoretical premises, we elaborate the notion of communication-connective action to highlight the communicational dimension as an axis both in organizational practices in connective action, as well as in activist media practices.

\subsection{Technopolitics as a hybrid strategy of contemporary activism}

The concept of technopolitics has become popular in contemporary academic reflection regarding ICT use by social movements and civil society organizations (Treré \& Barranquero, 2018). This perspective is linked to the study of technological mediation in the protest cycles of Arab Spring (2011), the 15M Movement (2011), Occupy Wall Street (2011) and the Nuit Debout (2016). Based on the study of the 15M Movement, Toret $(2013,2015)$ defines technopolitics as the as "the capacity for collective action online" (Toret, 2015, p. 62), by connected multitudes that make "tactical and strategic use of digital tools for organizational, communication and collective action" (Toret, 2013, p. 20). This theory proposes that the activist network, configured through connective action, becomes a collective political subject that makes strategic use of ICTs. Rovira (2019) proposes that social movements have taken advantage of ICTs, in three aspects: to extend the frameworks of meaning, to innovate in their repertoires of collective action and to extend their power and impact on a transnational scale. (2019, p. 45).

Beyond instrumentality and moving away from technological determinism, technopolitics proposes the existence of an integral connection between online and offline strategies. Technopolitics emphasizes a dynamic articulated in a multi-layered system consisting of a physical layer (urban space), a digital layer (transmedia space) and a mediatic layer (mediatic space) (Toret, 2015, p. 42). It therefore goes beyond the reductionism of cyberactivism anchored exclusively in the digital environment. The multi-layered system is configured as a symbiotic relationship that interweaves different components. Crucial 
are the concepts of the "augmented event"(Toret, 2013, 2015)and the "expanded public space"(Reguillo, 2017), that evoke synergistic feedback between the physical and virtual realms as an integrated whole: "from the web to the street, from the street to the online square"(Toret, 2013, p. 59). This convergence in both connected multitudes and the multilayered system has been defined as a networked system (Toret, 2013, p. 20).

The self-organizing and collaborative forms of the connected multitudes are constitutive of technopolitics. Toret (2013)characterizes this dynamic as constituting a network

system with a polycentric rhizomatic structure, hierarchy-less and lacking the central institutional figure, self-regulates autonomous. In this sense, Rovira (2019) proposes the notion of "technopolitics for collective self-determination", which emerges from a communicative power oriented to emancipatory action (2019, p. 45). The opportunities for interconnection, which allows technological mediation, are translated into physical and virtual communities driven by collective intelligence, where the organization emerges from a participatory co-construction. Thus, technopolitics operates as a "pattern of political selforganization in the network society" (Toret, 2015, p. 65). Activist networks-focused activities "that represents new forms of political subjectivation in a multidimensional and hybrid space" (Rovira, 2013, p. 115).

Based on the ecology of social movements and their media, Trere \& Barranquero (2018) highlight the potential of technopolitics for its capacity to generate inherently hybrid political actions. The authors argue that, in contemporary activist practices, socio-technical multiplicity makes it possible to overcome dichotomies (online-offline, old media-new media), which represents an innovative and strategic performativity (Treré \& Barranquero, 2018, p. 55). Treré (2019) has recently coined the concept of hybrid media activism, based on five axes: physical/digital convergence; agency by human/non-human actors; digital/non-digital technologies use; internal/external communication in social movements, and corporate/ alternative media. In this line, as proposed by José Candón-Mena (2019), a critical approach to technopolitics implies overcoming technological determinism; from a multidisciplinary perspective, contemplating the political, ideological, cultural and technological aspects of the actors: considering the relationship between these multiple spheres.

\section{Method: SNA and graph visualization}

SNA as a methodology for the study of social movements is very useful for understanding organizational interactions, for instance, the formation of coalitions, which, 
in turn, can throw useful light on collective action processes (Caiani, 2014). This relational approach allows us to explore the social interactions between civil society actors, political representatives and public institutions (Diani, 2002). Recent studies have incorporated advances in data science to research SNA. Aragón(2015), for instance, has explored the topology of the $15 \mathrm{M}$ network and the arrangement of its nodes (points of enunciation) through mathematical metrics that generate graphic maps.

To process the data, we used Gephi specialist software (open source and free access) for viewing network graphs. This tool detected nodes, edges, node degrees and clustersin the \#SOSPuebloShuar activist network and enabled us to establish variables for deeper exploration.The main concepts are explained as follows, based on Aragón (2015): A node is a point of enunciation, in the case of Twitter it corresponds to a user account. An edge is the link between two nodes, that is, user-user interactions in Twitter. The degree refers to the number of edges that affect a specific node, where two relationships are possible Indegree (receiving users - Twitter accounts that have been mentioned) and Outdegree (sending users - Twitter accounts that have mentioned other accounts). A cluster is a set of nodes that may have a higher or lower density of edges, reflecting stronger and weaker linkages, respectively.

\subsection{Data collection}

In the first phase of this study of the \#SOSPuebloShuar activist network, data was extracted from the Twitter platform using the Tweet Binder tool (a total of 32,835 tweets consisting of 5,287 original tweets and 27,548 retweets). The period of analysis was 16 December 2016 to 28 May 2018 (inclusive). According to the Twitter platform architecture, three types of relationships are possible: user-user, user-hashtagand hashtag-hashtag. Based on the research questions, our relational analysis variable was user-user, given that we only took original tweets into account in mapping key actors (nodes). A total of 1,857 tweets were ultimately stored in the dataset to which SNA was applied.

\subsection{Mapping the main actors (key nodes) RQ1}

According to RQ1, we apply the Eigenvector Centrality algorithm, which measures the influence of a node in the network, showing the connections of the nodes with other 
nodes that can be well connected (Aragón, 2015). Through this operation, the main actors (key nodes) were identified and coded according to the self-description of their Twitter account. Through this operation, the main actors (key nodes) were identified and systematized according to the self-description of their account in Twitter. It was systematized in six categories: non-governmental organizations, specialized media, activists, indigenous movement, public bodies and government politicians. Finally, we generated a visualization graph from the mapping of the most influential accounts (key nodes) in the network \#SOSPuebloShuar.

\subsection{Structural relations (clusters) RQ2}

By using the Modularity Class function, which measures the strength of network divisions into clusters, we detected the strategic communities (clusters) around the key nodes that we had mapped. In order to solve the RQ2, we systematized the type of relation between the key nodes,according with the notion of the social interactions reflect cooperation, disagreement or influence relationships (Caiani, 2014, p. 371).Considering the coincidence of the value of Modularity Class in the key nodes, we identified the main clusters, which we systematized in twotypes of prevailing relations: cooperation and disagreement. According to the six categories of actors that we mapped, the type of relation and taking into account the indegree and the outdegree values; we classified in two main groups: A) advocacy group, composed form a cooperative coalition of actors that represent the ecosocial activism; B) the opposite group, composed by the actors that defend the extractivism. This approach was the basis for the analysis to understand the reconfiguration of collective action of ecosocial activism, digitally mediated.

\subsection{Connective actionand convergent activism analysisRQ3}

To analyze the reconfiguration of the collective action in \#SOSPuebloShuar that we aimed in the RQ3, we used the notion of connective action (Bennett \& Segerberg, 2012) to Occupy Wall Street (and beyond and the networked opportunity structure, which suggests that the more interconnected the environment is, the more social movement acquires organizational and mobilization capacity (Cammaerts, 2012). Our strategy consisted in characterizing the political claims of the main actors (key nodes) that generated cooperation 
relations in the advocacy group and in the most important cluster of this group based in the coincide of value in the modularity class. To understand the correlation between the networked collective action and the optimization of political opportunities, we identified three types of political claims: ethnic-cultural, ecological-territorial and human rights.

\section{Results and discussion}

\subsection{Mapping the main actors in \#SOSPuebloShuar - RQ1}

Processing of the dataset of tweets using the Gephi software algorithms generated the following results at the macro level: 1,349 nodes (number of participating Twitter accounts); 1,933 edges (number of interactions between accounts); and 59 node communities revealing modularity. According to the Gephi connected components report, 1,321 nodes were strongly connected. Figure 1 shows the macrostructure of the \#SOSPuebloShuar activist network. For the \#SOSPuebloShuar network macrostructure, general values as follows were obtained: indegree (0 to 312 ), outdegree (0 to 60 ), and eigenvector centrality (0 to 1 ).

\section{FIGURE 1}

Macrostructure graph of the \#SOSPuebloShuar activist network. Generated from the Force Atlas 2 distribution algorithm

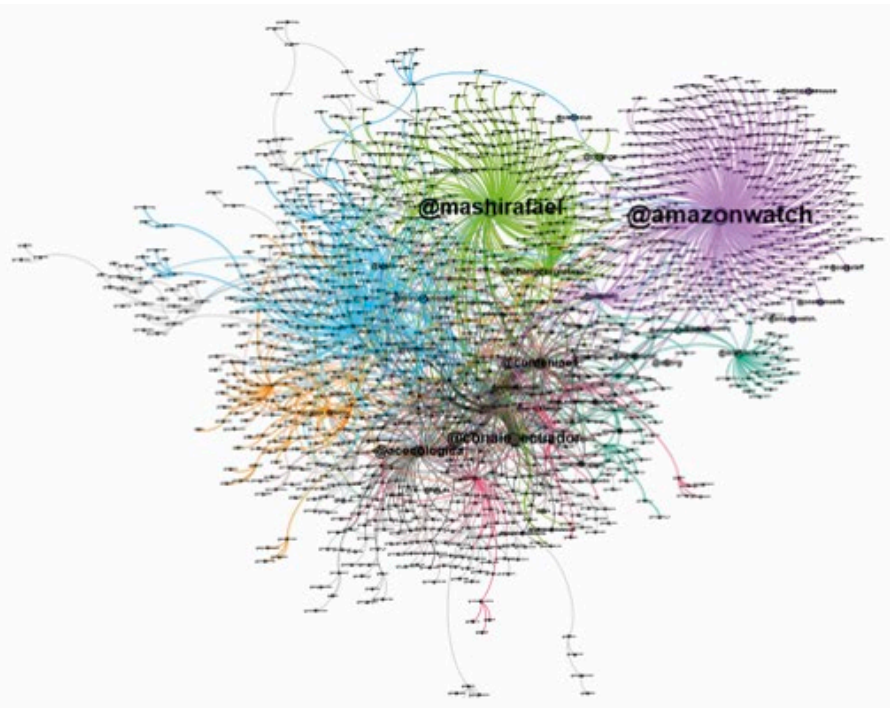


From the perspective of communication-connective action, the \#SOSPuebloShuar activist network is highly interconnected. Nearly all the nodes (97\%, 1321 of a total of 1349) are strongly connected and the average weighted degree (AVD) metric is 2.2 , meaning that each Twitter account is linked on average with 2.2 other users in the activist network. However, some network actors stand out not only for the quantity but also for the quality of their connections. The eigenvector centrality algorithm identified key accounts in the activist network, thereby addressing the RQ1: Who are the main actors that represent the key nodes of the network and what type of sector they represent? Twenty-five key nodes were identified and systematized from the self-description of their Twitter account. They were classified into six categories: non-governmental organizations, specialized media, activists, indigenous movement, public bodies, and government politicians. Table 1 and Figure 2 represent the most influential Twitter accounts in \#SOSPuebloShuar. That means, i.e., the most important accounts according to their connective capacity with other users (nodes with a high rate of interconnectivity with other nodes).

\section{TABLE 1}

The most important nodes of the \#SOSPuebloShuar network, categorized according to the sector they represent

\section{Group classification: ADVOCACY GROUP}

\section{SECTOR: ONGS}

\begin{tabular}{|c|c|c|c|c|c|}
\hline User & Details & Indegree & Outdegree & $\begin{array}{c}\text { Modularity } \\
\text { Class }\end{array}$ & $\begin{array}{c}\text { Eigenvector } \\
\text { Centrality }\end{array}$ \\
\hline @amazonwatch & Amazon Watch & 312 & 17 & 17 & 1 \\
\hline @acecologica & Accion Ecologica & 69 & 3 & 3 & 0.61305406 \\
\hline @acecologica! & Accion Ecologica & 3 & 0 & 3 & 0.27075336 \\
\hline @change & Change & 6 & 0 & 44 & 0.36454637 \\
\hline @fidh_es & $\begin{array}{c}\text { International Federation for } \\
\text { Human Rights (FIDH) }\end{array}$ & 6 & 0 & 54 & 0.23156305 \\
\hline
\end{tabular}




\section{Group classification: ADVOCACY GROUP}

\section{SECTOR: ONGS}

\begin{tabular}{|c|c|c|c|c|c|}
\hline User & Details & Indegree & Outdegree & $\begin{array}{c}\text { Modularity } \\
\text { Class }\end{array}$ & $\begin{array}{l}\text { Eigenvector } \\
\text { Centrality }\end{array}$ \\
\hline @onu_derechos & $\begin{array}{c}\text { South America Office of the UN } \\
\text { High Commissioner for Human } \\
\text { Rights (UNHR-SA) }\end{array}$ & 16 & 0 & 2 & 0.19056578 \\
\hline @coicaorg & $\begin{array}{c}\text { Coordinator of the Indigenous } \\
\text { Organizations of the Amazon } \\
\text { Basin (COICA) }\end{array}$ & 7 & 5 & 59 & 0.15428061 \\
\hline
\end{tabular}

\section{SECTOR: SPECIALIST MEDIA}

\begin{tabular}{|c|c|c|c|c|c|}
\hline User & Details & Indegree & Outdegree & $\begin{array}{l}\text { Modularity } \\
\text { Class }\end{array}$ & $\begin{array}{l}\text { Eigenvector } \\
\text { Centrality }\end{array}$ \\
\hline @intentlcry & IC Magazine & 27 & 0 & 15 & 0.35101262 \\
\hline @chekhovdispatch & $\begin{array}{l}\text { Pedro Canché Independent } \\
\text { Journalism }\end{array}$ & 2 & 0 & 15 & 0.28308786 \\
\hline @indiancountry & Indean Country Today & 2 & 0 & 17 & 0.26749998 \\
\hline @mongabaylatam & $\begin{array}{c}\text { Mongabay Latam, environmental } \\
\text { news platform }\end{array}$ & 3 & 0 & 3 & 0.19901987 \\
\hline @sospuebloshuar & SOS Pueblo Shuar & 8 & 12 & 3 & 0.13757133 \\
\hline @semana_56 & Semana 56, now Chakana News & 3 & 34 & 0 & 0.1264822 \\
\hline
\end{tabular}

\section{SECTOR: ACTIVIST}

\begin{tabular}{c|c|c|c|c|c} 
User & Details & Indegree & Outdegree & $\begin{array}{c}\text { Modularity } \\
\text { Class }\end{array}$ & $\begin{array}{c}\text { Eigenvector } \\
\text { Centrality }\end{array}$
\end{tabular}

\begin{tabular}{|c|c|c|c|c|c|}
\hline @pepeacacho & $\begin{array}{l}\text { Pepe Acacho, former head of } \\
\text { CONAIE }\end{array}$ & 2 & 0 & 3 & 0.19637903 \\
\hline @jaredleto & Jared Leto, international artist & 31 & 1 & 17 & 0.1914058 \\
\hline @jherreramoroch & $\begin{array}{l}\text { Jorge Herrera Morocho, former } \\
\text { president of CONAIE }\end{array}$ & 3 & 0 & 3 & 0.19979478 \\
\hline @seve_sharupi & $\begin{array}{l}\text { Severino Sharupi, former head of } \\
\text { CONAIE }\end{array}$ & 12 & 1 & 0 & 0.15992182 \\
\hline
\end{tabular}




\section{Group classification: ADVOCACY GROUP}

\section{SECTOR: ACTIVIST}

\begin{tabular}{|c|c|c|c|c|c|}
\hline User & Details & Indegree & Outdegree & $\begin{array}{c}\text { Modularity } \\
\text { Class }\end{array}$ & $\begin{array}{c}\text { Eigenvector } \\
\text { Centrality }\end{array}$ \\
\hline @amazonmiller & $\begin{array}{c}\text { Andrew E. Miller, Amazon Watch } \\
\text { Advocacy Director }\end{array}$ & 7 & 6 & 15 & 0.12262648 \\
\hline
\end{tabular}

\section{SECTOR: INDIGENOUS MOVEMENT}

\begin{tabular}{|c|c|c|c|c|c|}
\hline User & Details & Indegree & Outdegree & $\begin{array}{l}\text { Modularity } \\
\text { Class }\end{array}$ & $\begin{array}{l}\text { Eigenvector } \\
\text { Centrality }\end{array}$ \\
\hline @conaie_ecuador & $\begin{array}{l}\text { Conference of Indigenous } \\
\text { Nationalities of Ecuador (CONAIE) }\end{array}$ & 42 & 21 & 3 & 0.67933438 \\
\hline @confeniae1 & $\begin{array}{l}\text { Conference of Indigenous } \\
\text { Nationalities of the Ecuadorian } \\
\text { Amazon (CONFENIAE) }\end{array}$ & 36 & 31 & 3 & 0.5697185 \\
\hline
\end{tabular}

\section{Group classification: OPPOSITE GROUP}

\section{SECTOR: PUBLIC BODIES}

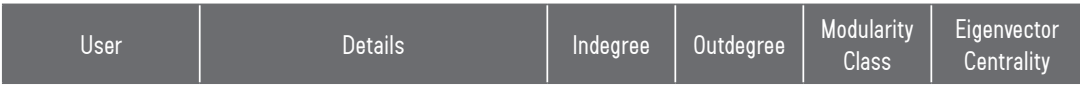

\begin{tabular}{|l|l|l|l|l|l|}
\hline$@$ Mmininteriorec & Ministry of the Interior & 15 & 0 & 8 & 0.40934836 \\
\hline @ambiente_ec & Ministry of the Environment & 6 & 0 & 44 & 0.27728843 \\
\hline
\end{tabular}

\section{SECTOR: GOVERNMENT POLITICIANS}

\begin{tabular}{|c|c|c|c|c|c|}
\hline User & Details & Indegree & Outdegree & $\begin{array}{c}\text { Modularity } \\
\text { Class }\end{array}$ & $\begin{array}{c}\text { Eigenvector } \\
\text { Centrality }\end{array}$ \\
\hline @mashirafael & $\begin{array}{r}\text { Rafael Correa, former president } \\
\text { of Ecuador }\end{array}$ & 142 & 0 & 44 & 0.95284215 \\
\hdashline @lenin & $\begin{array}{c}\text { Lenin Moreno, presidential } \\
\text { candidate for Ecuador }\end{array}$ & 32 & 0 & 8 & 0.2332182 \\
\hdashline
\end{tabular}




\section{FIGURE 2 \\ Most important nodes in the \#SOSPuebloShuar network according to the Eigenvector Centrality algorithm. Edges: blue (indegree); fuchsia (outdegree); yellow (two-way)}

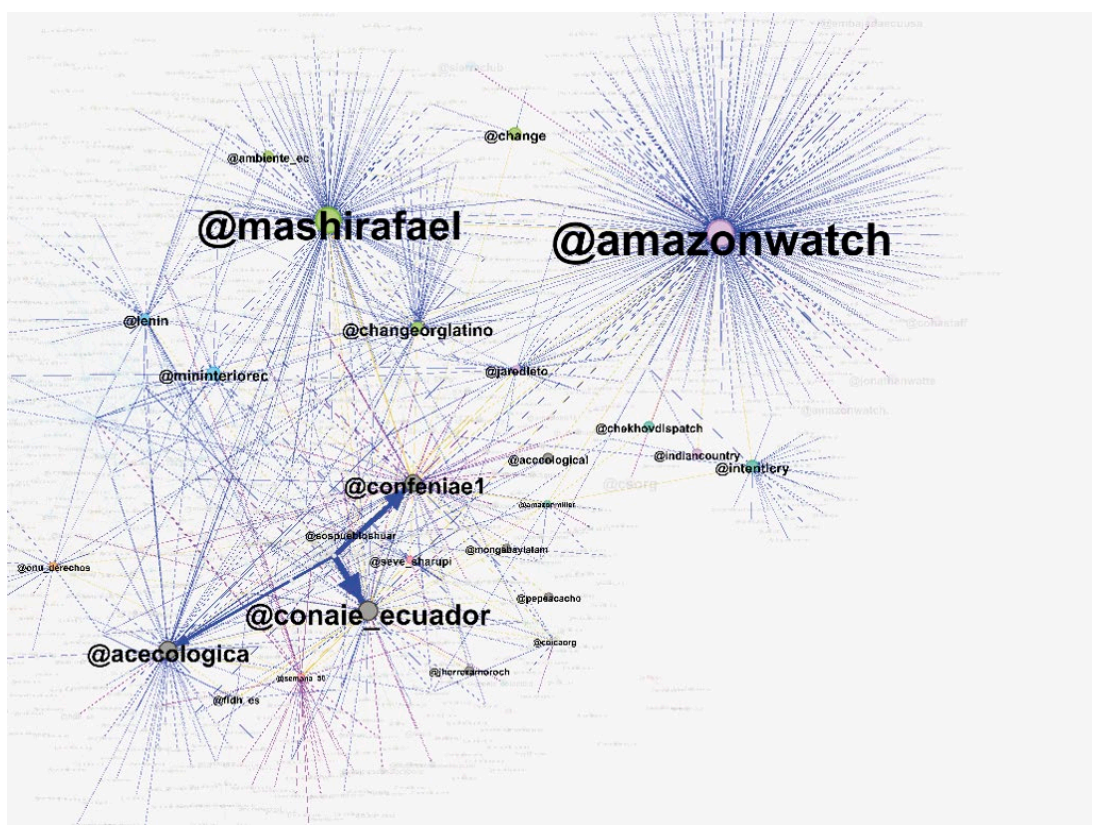

5.2 Structural relations in the main actors in \#SOSPuebloShuar - RQ2

According to the relational analysis that suggests that the position and interactions of actors in a network can indicate cooperation, disagreement or influence relations (Caiani, 2014), we detected cooperation relations as a coalition among twentyone main actors, and disagreement relations in four main actors on \#SOSPuebloShuar. This result was determined after considering the value of modularity class, the values of indegree and outdegree, and the sector represented by the key nodes in the sociohistorical-political context. 
Responding to RQ2 implied the systematization of these two groups according to the type of relations: A) the advocacy group, composed of the actors who generated coalitions and who represent ecosocial activism: NGOs (8), specialist media (6), activists (5), indigenous movement (2). The integration of this political force, which constitutes the advocacy group, shows the heterogeneity of actors of civil society converging in a political alliance. B) the opposite group composed of the actors who defend mining: public bodies (2) and government politicians (2)They represent the political adversary of the ecosocial activism due to the position in favour of extractivism. (See table 1).

Since activism represents conscious and deliberate political opposition, the most significant clusters were identified around the advocacy group (cluster N. 3 and cluster N.17) and the opposition group (cluster N. 8 and cluster N.44). Figure 3 illustrates the graph of these main clusters. Also, considering that the cluster with the highest density was cluster N.3, figure 4 shows its graph for in-depth examination. The composition of the advocacy group and the opposite group was explored to answer the RQ2: What kind of structural relations (cooperation, disagreement, influence) exist among the key nodes in the network? The figures and an analysis of the composition of both groups are presented below.

\section{FIGURE 3}

\section{Four main clusters in \#SOSPuebloShuar}

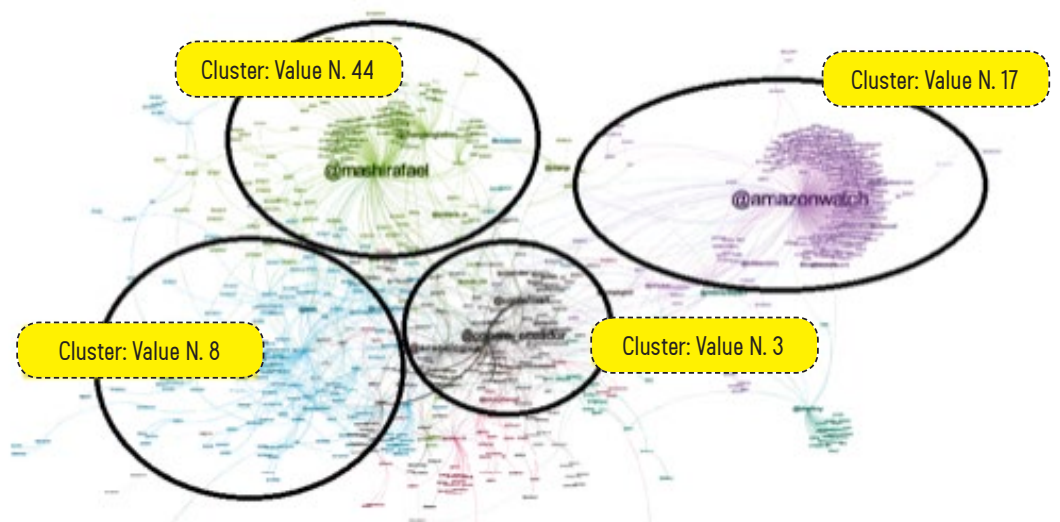




\section{FIGURE 4 \\ Cluster: Value N.3. Main cluster of nodes with modularity class value 3, within the \#SOSPuebloShuar advocacy group. This cluster is composed by the greatest number of influential nodes with a high rate of interconnectedness}

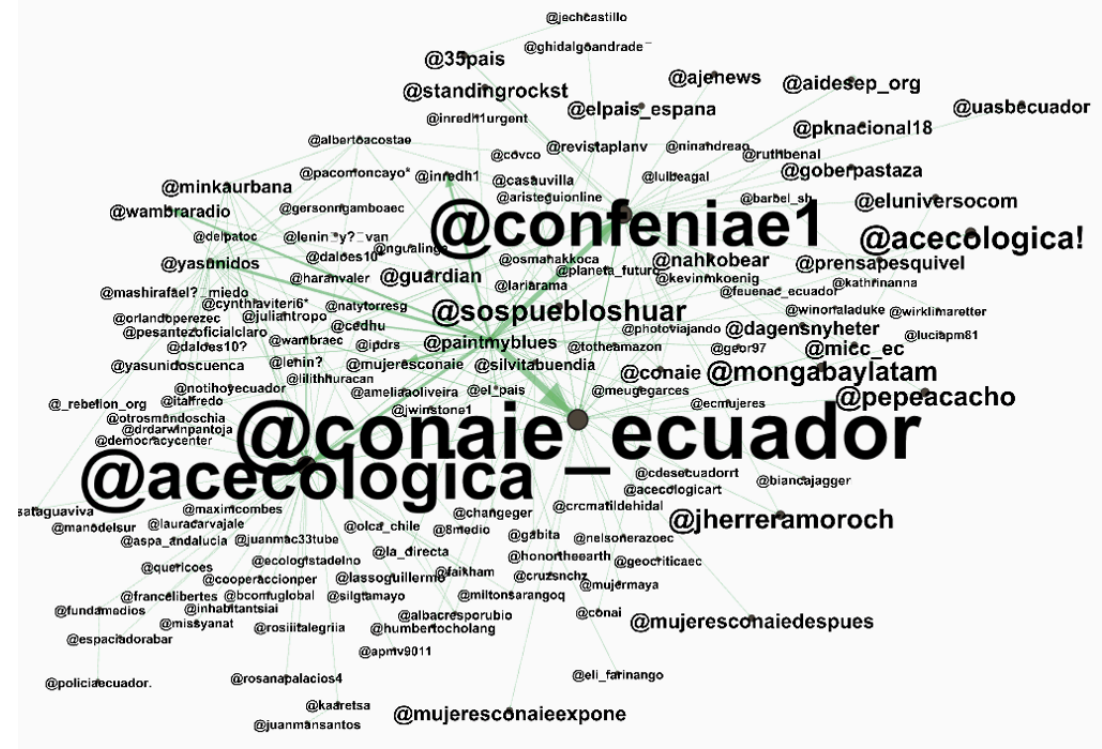

The advocacy group is mainly composed of several national and international NGOs, including, most notably (according to eigenvector centrality), Amazon Watch (indegree 312, outdegree 17), and, at the regional level, Change Latin-American (indegree 54, outdegree 2) and COICA (indegree 7, outdegree 5), and finally, the local NGO Acción Ecológica (indegree 69, outdegree 3), which is fourth in terms of impact but also central to the sociopolitical context of the ecosocial activism. Acción Ecológica proposed the creation of a peace and truth commission to investigate the rights violations of indigenous peoples and the environmental impact of mining on the Cordillera del Cóndor. In December 2016, the Ecuadorian Ministry Coordinating Internal and External Security requested the dissolution of Acción Ecológica, claiming that it was departing from its foundational objectives approved in 1986. (Pressenza International Press Agency, 2016). Finally, although the UNHR-SA and FIDH were mentioned in tweets, they are not enunciated. 
Notable accounts in the advocacy group are the specialist media, in terms of outdegree, Chakana News, which focuses on environmental issues (outdegree 34) and @ SOSPuebloShuar, which defends nature in the Shuar territory (outdegree 12), was derived from the corresponding hashtag as a hybridization of practices in the communicational and political spheres. Considering Bennett \& Segerberg (2014), @SOSPuebloShuar embodies a collective political subject of ecosocial claim and, at the same time, the discursive axis of the network movement. Regarding indegree, the most important account was that of the international IC Magazine, which defends the rights of indigenous peoples around the world (indegree 27) and featured because of its coverage of the socio-environmental conflicts of the Shuar people. Of lesser significance are Mongabay Latam, Pedro Canché Independent Journalism and Indian Country Today (indegree 3, 2 and 2, respectively).

In third and position in the advocacy group are the personal accounts of national and international activists. The most prominent node is that reflecting the account of Andrew E. Miller, Advocacy Director for Amazon Watch (outdegree 6) and, linked to the same NGO, the international artist Jared Leto, who joined the initiative at the request of Amazon Watch. Noteworthy is the fact that the modularity class (in this case 17 and 15) is a common factor in these nodes, which would explain the high interconnectivity index (Table 1) and the connective action of the activists. Playing a less central role are the accounts of activists linked to the indigenous movement, namely, Severino Sharupi and Jorge Herrera Morocho, former leader and former president of CONAIE, respectively, and Pepe Acacho, indigenous leader of the Shuar people (outdegree 1 and indegree 3 and 2, respectively); the last two of these three accounts have no record of tweet generation. In contrast, in fourth position the institutional accounts of the indigenous movement are leading network actors in the advocacy group. CONAIE (indegree 42, outdegree 21) and CONFENIAE (indegree 36, outdegree 31) are third and fifth in terms of importance according to eigenvector centrality (Table 1). These two accounts also share the modularity class (i.e., 3) identified as the cluster of nodes with the most important network actors (Table 1).

In the other hand, the opposition group is formed entirely of actors of institutions, politicians and government and public figures whose stance is pro-mining. Notable is the account of Rafael Correa, former president of Ecuador, second in importance according to eigenvector centrality (indegree 142), while the account of the then presidential candidate, Lenin Moreno, also had a high indegree index of 32 (Table 1). The actors of the opposition group are notable for mentions, i.e., as recipients of tweets. Considering that \#SOSPuebloShuar represents the ecosocial activism, it is inferred that the exogroup was scolded by the demands of the advocacy group. This dynamic is reflected, in the 
disagreement relationships established with the opposition group. According to this logic, the nodes of the Ministry of the Interior and the Ministry of the Environment (indegree indices of 15 and 6 , respectively) are identified as responsible for human rights violations and socio-environmental conflicts. Indeed, an indicator of their belongingness to the same cluster of nodes is the fact that the opposition group actors all share the same modularity classes (i.e., 44 and 8). The opposition group broadly represents the state position that defends an economic development model anchored to natural resource exploitation.

\subsection{Convergent activism analysis: the reconfiguration of the networked collective action strategy - RQ3}

According to the concept of a networked society, in a social structure with a high degree of technologically mediated interconnectivity, power lies in the ability to network and to connect networks so as to generate cooperation and optimize resources (Castells, 2012, p. 79). In this sense, political use of the \#SOSPuebloShuar hashtag constitutes a connective action device (Bennett \& Segerberg, 2012)to Occupy Wall Street (and beyond, with emancipatory potential, within the framework of the structure of networked opportunities, which suggests that the more interconnected the environment is, the more the social movement acquires organizational and mobilization capacity (Cammaerts, 2012). The politicization of a hashtag overcomes the instrumental reductionism implied by technological determinism; the hashtag \#SOSPuebloShuar is not just an indexing mechanism in Twitter, rather, as a technical-political device, it represents the interconnectivity capacity of numerous actors that together reflect a hybrid collective political subject. This interpretation is justified by the fact that the advocacy group network actors belonging to modularity class 3 (Figure 4) have an average of five links with other organizations in the same cluster -i.e., the Average Weighted Degree (AWD) is 5-. When this measure is high, it indicates a high degree of activism among actors in the same sector (Caiani, 2014, p. 382).

The \#SOSPuebloShuar ecosocial activism network is based on cooperative relationships between the main actors in the advocacy group.To solve the RQ3, we applied SNA interpretation guidelines, a high number of links between actors is considered to indicate shared objectives, ideological closeness or common interests (Caiani, 2014, p. 374). The cluster of nodes with modularity class 3 concentrates most of the advocacy group (Figure 4). Cluster N. 3 is composed by 130 nodes and 187 edges at depth level 1 (i.e., reflecting primary connections).According to the connected components report, 
125 nodes are strongly connected. Communication-connective action facilitates strategic cooperation by optimizing the resources and potentials of the networked actors in the advocacy group. To better understand the cooperative relationships between key actors in this cluster, we classified then by sector and political agenda and identified them in terms of three categories of claims-demands: ethnic-cultural, ecological-territorial and human rights. In this sense, \#SOSPuebloShuar represents a form of ecosocial converging activism that is configured around strategic alliances to drive collective network action.

\section{FIGURE 5}

Diagram on the cooperative relations between the sectors represented in the advocacy group (left) and diagram of ecosocial activism and convergence of demands (right)
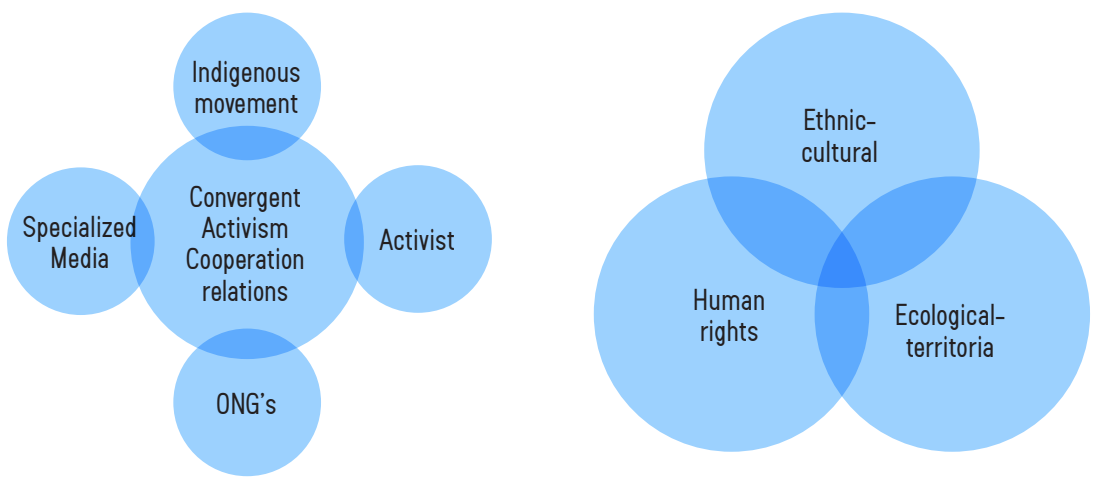

The ethnic-cultural category broadly reflects the indigenous movement (maximumminimum AWD 191-33): CONAIE, CONFENIAE, @SOSPuebloShuar, CONAIE Women (@ MujeresConaie) and the Cotopaxi Indigenous and Peasant Movement (@Micc_Ec). Historically, the demands of the indigenous movement in Ecuador have been linked to their struggle for collective rights and self-determination - rights which are recognized in the principles of plurinationality and interculturality (Constitution of Ecuador, 2008). They want their ancestral territories to be respected and reject mining activities because of the socio-environmental conflicts they generate. They also denounce, as a subalternization of their citizenship, the breach of the free and informed prior consultation undertaking and they claim 
that their culture is incompatible with the state-proposed economic development model anchored to resource exploitation policies.

The ecological-territorial category reflects the accounts of environmental movements and academic activists(maximum-minimum AWD 165-12), composed as follows.From the environmental sector:Acción Ecológica; Yasunidos and ecological movement against oil explorations in the Amazon, called Yasunidos (@Yasunidos and @ YasunidosCuenca); an urban collective against large-scale mining called Minka Urbana (@MinkaUrbana); and Listen to the Amazon (@ToTheAmazon), a platform to defend the Amazon and its indigenous peoples.From the academic sphere:Alberto Acosta (@ AlbertoAcostaE), academic and activist; María Arboleda (@lariarama), academic and anti-corruption activist.The core ecological-territorial defence links territorial rights, the collective rights of indigenous people ${ }^{1}$ with the rights of nature ${ }^{2}$ (recognized in the Constitution of Ecuador, 2008).

Regarding the human rights category, institutional and personal accounts are equally relevant (maximum-minimum AWD 419-26). Institutional accounts include the Ecumenical Human Rights Commission (@Cedhu), the Regional Foundation for Human Rights Advisory (@ Inredh1) and the human rights focused Wambra, Community Digital Media (@WambraEC). Notable personal accounts are those of the visual artist and activist Pit Becker (@paintmyblues), the most influential intermediation node in the subnetwork (with the highest AWD, 419), followed by Silvia Buendía (@silvitabuendia), the human rights defender. Given that human rights violations in indigenous territories lead to forced displacements, militarization and the criminalization of social protest, it is remarkable that it is those accounts that mainly lead demands in favour of human rights.

Maristella Svampa (2019)explains that contemporary socio-environmental struggles in Latin America are characterized by an innovative cross-fertilization between two political-ideological matrices: A) the indigenous peasant who has historically defended cultural and territorial rights, and $B$ ) the autonomous ecologist whose narrative is manifested by groups, activists, academics, etc. This tendency, which Svampa labels an "ecoterritorial

1 The Constitution of Ecuador (2008) recognizes and guarantees the collective rights of indigenous peoples and nationalities, which include maintaining possession of ancestral lands and territories; as well as participation in prior, free and informed consultation on plans and programmes for the dispossession, exploitation and commercialization of non-renewable resources in their territories (Art. 57).

2 The Constitution of Ecuador recognizes Rights of Nature. State guarantees the maintenance and regeneration of ecosystems life cycles; it promotes that every person, community, town or indigenous nationality may demand from the public authority the fulfillment of the Rights of Nature (Art. 71). 
turn', implies a defence of several kinds of rights, including cultural rights, territorial rights, collective indigenous rights, the rights of nature and the commons ${ }^{3}$, resulting in socioenvironmental justice (Svampa, 2019, p. 44). This convergent ecosocial activism is evident in the \#SOSPuebloShuar which reconfigures collective action based on connective action among the actors in the advocacy group, taking advantage of the political opportunities of the various sectors they represent. This amplifies their communication and activist contingency repertoire.

\section{Conclusions}

According to our SNA results, we conclude that the \#SOSPuebloShuar activism network responds to technopolitical (Toret, 2015) criteria in how it strategically takes advantage of online mediation opportunities (Cammaerts, 2012) to generate cooperation relationships. Noteworthy is the configurative capacity of the advocacy group in generating a cohesive political alliance. This online networked movement operates based on harnessing emerging strategic cooperation as a form of collective online action that enhances the resources and political opportunities of the corresponding actors. Communicationconnective action developed by networked actors configures the convergent activism reflected in ethnic-cultural, ecological-territorial and human rights demands. Indeed, \#SOSPuebloShuar represents synergistic convergent activism focused on an ecosocial issue. The ability to network and to connect networks creates a hybrid collective political subjectivity that magnifies its emancipatory power.

The analysisof the topology of the \#SOSPuebloShuar network throws light on the organizational and communicational activism practices in the context of contemporary media ecologies. This activist network operates as a socio-technical, socio-communicative and socio-political channel that enhances agency by interrelating and connecting actors. Civil society cooperation relationships (between the indigenous movement, national and international NGOs, environmental groups, alternative media, human rights organizations, activists and academics) point to political communication-connective action strategies that configure the online collective actions of the movement. \#SOSPuebloShuar, in fact,

3 The commons refer to assets that a group, community or society uses in common and that are not privately owned. The commons include natural and cultural resources; in relation to the environment is concerned, e.g. air, water and land(0strom, 1990). 
is illustrative of contemporary transformations of activism. In organizational practices, cooperative relationships could well be interpreted as the maximum expression of Svampa's ecoterritorial turn (2019). In communication practices, the dynamics of this activist network can be interpreted in terms of hybrid mediatic activism (Treré, 2019).

\section{Bibliography}

Aragón, P. (2015). Metodologías asociadas al análisis de redes sociales. In J. (Coord).Toret (Ed.), Tecnopolítica y 15M: la potencia de las multitudes concectadas. Un estudio sobre la gestación y explosición del 15M. (pp. 265-269). Barcelona: Editorial UOC.

Báez, M., Bayón, M., Larreátegui, F., Moreano, M., \& Sacher, W. (2016). Entretelones de la megaminería en el Ecuador. Informe de visita de campo en la zona del megaproyecto minero Mirador, parroquia Tundayme, cantón El Pangui, provincia de Zamora-Chinchipe, Ecuador.Quito. Retrieved from http://www.accionecologica.org/ component/content/article/1865-entretelones-de-la-megamineria-en-ecuador

Bell, D. (2006). Cybercultures: Cyberculture, Cyberpolitics, Cybersociety. New York-London: Routledge.

Bennett, W. L., \& Segerberg, A. (2012). The logic of connective action: Digital media and the personalization of contentious politics. Information Communication and Society, 15(5), 739-768. https://doi.org/10.1080/1369118X.2012.670661

Bennett, W. L., \& Segerberg, A. (2014). La comunicación en los movimientos. De los medios de comunicación de masas a las redes sociales. Retrieved July 14, 2018, from https://telos.fundaciontelefonica.com/archivo/numero098/de-los-mediosde-comunicacion-de-masas-a-las-redes-sociales/

Caiani, M. (2014). Social Network Analysis. In D. della Porta (Ed.), Methodological Practices in Social Movement Research (pp. 368-396). Oxford University Press.

Cammaerts, B. (2012). Protest logics and the mediation opportunity structure. European Journal of Communication, 27(2), 117-134. https://doi. org/10.1177/0267323112441007 
Candón-Mena, J. (2019). Movimientos conectados: Abordajes tecnopolíticos. IC-Revista Científica de Comunicación e Información, 16, 23-35. https://doi. org/10.12795/IC.2019.i19.01

Castells, M. (2009). Comunicación y poder. Madrid: Alianza Editorial.

(2012). Redes de indignación y esperanza. Madrid: Alianza Editorial.

Colectivo de Investigación y Acción Psicosocial Ecuador. (2017). La herida abierta del Cóndor. Vulneración de derechos, impactos socioecológicos y afectaciones psicosociales provocados por la empresa minera china EcuaCorriente S.A. y el Estado ecuatoriano en el Proyecto Mirador. (Primera Ed). Quito: El Chasqui.

Confederación de Nacionalidades Indígenas del Ecuador. (2017). Asamblea de la CONAIE concluyó con plantón en solidaridad con Agustín Wachapá. Retrieved February 5, 2020, from https://conaie.org/2017/02/01/asamblea-la-conaieconcluyo-planton-solidaridad-agustin-wachapa/

Costanza-Chock, S. (2012). Mic Check! Media Cultures and the Occupy Movement. Social Movement Studies, 11(3-4), 375-385. https://doi.org/10.1080/147428 37.2012.710746

Diani, M. (2002). Network Analysis. In B. Klandermans \& S. Staggenborg (Eds.), Methods of Social Movement Research (pp. 173-201). Minneapolis-London: University of Minnesota Press.

El Comercio. (2016). Activistas se volvieron a reunir en el centro de Quito por la situación en Morona Santiago. El Comercio. Retrieved from https://www.elcomercio. com/actualidad/activistas-planton-quito-conflicto-moronasantiago.html

---- (2017). Audiencia de Habeas Corpus por líder shuar detenido se realiza en Cotopaxi. Retrieved from https://www.elcomercio.com/actualidad/audienciahabeascorpus-lidershuar-cotopaxi-agustinwachapa.html

Foro Social Panamazónico. (2017). Veredicto del Tribunal: Justicia y Defensa de Ios Derechos de las Mujeres Panamazónicas y Andinas. Retrieved October 9, 2019, from http://www.forosocialpanamazonico.com/veredicto-del-tribunal-justicia-ydefensa-de-los-derechos-de-las-mujeres-panamazonicas-y-andinas/ 
Kuo, R. (2018). Racial justice activist hashtags: Counterpublics and discourse circulation. New Media and Society, 20(2), 495-514. https://doi. org/10.1177/1461444816663485

Latour, B. (2005). Reassembling the Social. An Introduction to Actor-NetworkTheory. New York: Oxford University Press.

Mattoni, A. (2013). Repertories of comunication in social movement processes. In B. Cammaerts, A. Mattoni, \& P. McCurdy (Eds.), Mediation and protest movements (pp. 39-56). Bristol, UK/Chicago, USA: Intellect.

McCarthy, J., \& Zald, M. (1977). Resource Mobilization and Social Movements. Americal Journal of Sociology, 82, 1212-1241.

Ostrom, E. (1990). Governing the commons The evolution of institutions for collective action. New York: Cambridge University Press.

Passy, F. (2002). Social Networks Matter. But How? In M. Diani \& D. McAdam (Eds.), Social movement analysis. Relational Approaches to Collective Action. (pp. 2149). Oxford University Press. https://doi.org/10.1093/0199251789.003.0002

Pérez-Altable, L., \& Blanco, S. (2016). Social movements and network analysis in Tunisia before the Arab Spring. Hipertext.Net: Anuario Académico Sobre Documentación Digital y Comunicación Interactiva, 0(14), 1-20. https://doi. org/10.2436/20.8050.01.30

Pressenza International Press Agency. (2016). Urgente comunicado por el cierre de Acción Ecológica. Retrieved from https://www.pressenza.com/es/2016/12/ urgente-comunicado-por-el-cierre-de-accion-ecologica/

Rambukkana, N. (2015). Hashtag Publics. The power and Politcs of Discursive Networks. New York: Peter Lang Publishing, Inc.

Reguillo, R. (2017). Paisajes insurrectos. Jóvenes, redes y revueltas en el otoño civilizatorio. España: Ned.

---- (2018). Comunicación distribuida, enmascarada y conectiva. Retrieved March 7, 2019, from https://www.youtube.com/watch?v=u406HvMzOWY 
Rovira, G. (2013). De las redes a las plazas: la web 2.0 y el nuevo ciclo de protestas en el mundo. Acta Sociológica. Centro de Estudios Sociológicos, FCPyS y UNAM, Núm. 62, 105-134.

---- (2017). Activismo en red y multitudes conectadas. Comunicación y Acción en la era del Internet. México: Icaria - Universidad Autónoma Metropolitana - HDCS Publicaciones.

---- (2019). Tecnopolítica para la emancipación y para la guerra : acción colectiva y contrainsurgencia. IC-Revista Científica de Comunicación e Información, 16, 39-83. https://doi.org/10.12795/IC.2019.i19.02

Sacher, W. (2017). Ofensiva megaminera china en los Andes. Acumulación por desposesión en el Ecuador de la "Revolución Ciudadana." Quito: Abya-Yala.

Sierra, F. (2017). Tecnopolítica y nuevo sensorium. Notas para una teoría de la cibercultura y la acción colectiva. In F. Sierra \& T. Gravante (Eds.), Tecnopolítica en América Latina y el Caribe (pp. 23-44). Quito-Salamanca: Ciespal.

Svampa, M. (2019). Las fronteras del neoextractivismo en América Latina. Conflictos socioambientales, giro ecoterritorial y nuevas dependencias. Alemania: Calas Maria Sibylla Merian Center.

Tarrow, S. (1997). El poder en movimiento. Los movimientos sociales, la acción colectiva y la política. Madrid: Alianza Editorial.

Tascón, M., \& Quintana, Y. (2012). Ciberactivismo. Las nuevas revoluciones de las multitudes conectadas. Madrid: Catarata.

Tilly, C., \& Wood, L. (2010). Los movimientos sociales, 1768-2008. Desde sus origenes a Facebook. Barcelona: Crítica.

Toret, J. (Coord). (2013). Tecnopolítica: la potencia de las multitudes conectadas. El sistema red 15M, un nuevo paradigma de la política distribuida.IN3 Working Paper Series - Internet Interdisciplinary Institude UOC. Barcelona. Retrieved from https://tecnopolitica.net/sites/default/files/1878-5799-3-PB (2).pdf 
Toret, J. (Coord). (2015). Tecnopolítica y 15M: La potencia de las multitudes conectadas. Un estudio sobre la gestación y explosión del 15M. Barcelona: UOC Ediciones.

Treré, E. (2019). Hybrid Media Activism: Ecologies, Imaginaries, Algorithms. London \& New York: Routledge.

Treré, E., \& Barranquero, A. (2018). Tracing the Roots of Technopolitics: Towards a North-South Dialogue. In F. S. Caballero \& T. Gravante (Eds.), Networks, Movements and Technopolitics in Latin America. Critical Analysis and Current Challenges. (pp. 43-63).

Van de Donk, W., Loader, B. D., Nixon, P. G., \& Rucht, D. (Eds.). (2004). Cyberprotest. New Media, Citizens and Social Movements (Routledge). London \& New York.

Xu, W. W. (2020). Mapping Connective Actions in the Global Alt-Right and Antifa Counterpublics. International Journal of Communication, 14, 1070-1091. 